Article

\title{
Debunking Political Disinformation through Journalists' Perceptions: An Analysis of Colombia's Fact-Checking News Practices
}

\author{
Carlos Rodríguez-Pérez ${ }^{1, *}$, Francisco J. Paniagua-Rojano ${ }^{2}$ and Raúl Magallón-Rosa ${ }^{3}$ \\ ${ }^{1}$ Department of Journalism, University of Ibagué, 730002 Ibagué, Colombia; E-Mail: carlos.rodriguez@unibague.edu.co \\ 2 Department of Journalism, University of Malaga, 29071 Malaga, Spain; E-Mail: fjpaniagua@uma.es \\ ${ }^{3}$ Department of Communication, Carlos III University of Madrid, 28903 Getafe, Spain; E-Mail: raul.magallon@uc3m.es \\ * Corresponding author
}

Submitted: 17 June 2020 | Accepted: 27 August 2020 | Published: 3 March 2021

\begin{abstract}
Fact-checking alliances emerged worldwide to debunk political disinformation in electoral contexts because of social concerns related to information authenticity. This study, thus, included the Latin American context in fact-checking journalism studies as a journalistic practice to fight political disinformation. Through analyzing RedCheq, the first fact-checking journalism alliance in an electoral regional context led by Colombiacheck, 11 in-depth interviews were conducted to identify the perceptions of regional fact-checkers regarding the usefulness of this journalistic practice, its achievements, and the key aspects for incorporating fact-checking into the regional media ecosystem. The study results revealed that RedCheq achieved the goal of fighting disinformation, and that fact-checking developed as transformational leverage for the regional media. Regional journalists perceived fact-checking as an element that restores credibility and social trust in regional media as the epistemology of this journalistic practice neglects the power pressure and dissemination of official narratives. Finally, this study highlighted how fact-checking journalism contributes to the democratic quality and civic empowerment in silenced and polarized environments. In addition, it discussed the need to expand fact-checking journalism's coverage to new geographical areas and improve journalists' professional competencies and training, thereby enabling them to function as using verification tools based on regional journalists' requirements.
\end{abstract}

\section{Keywords}

Colombia; disinformation; elections; fact-checking; journalism; political communication; political journalism; verification

Issue

This article is part of the issue "Disinformation and Democracy: Media Strategies and Audience Attitudes" edited by Pere Masip (University Ramon Llull, Spain), Bella Palomo (University of Málaga, Spain) and Guillermo López (University of Valencia, Spain).

(C) 2021 by the authors; licensee Cogitatio (Lisbon, Portugal). This article is licensed under a Creative Commons Attribution 4.0 International License (CC BY).

\section{Introduction}

This study analyzes the fact-checking RedCheq collaborative project, which is the first alliance of checkers in Colombia that was established to fight disinformation prevailing in the Colombian regional elections in 2019. Online disinformation campaigns threaten fair elections, which are core processes for achieving the democratic good of accountable political representation (Tenove, 2020). The initiative was developed in August 2019 with the participation of journalists, media, universities, and civil society organizations from across the country. These participants attended training workshops to be able to verify content and information during the electoral campaigns; limit the collateral effects of fake and deceitful information related to candidates, political parties, and processes and party platforms; and thoroughly monitor and examine regionally coded electoral public discourses.

The RedCheq collaborative initiative is based on other existing initiatives launched by First Draft, such as CrossCheck in France, Electionland in the US, Checkpoint 
in India, and Comprobado in Spain. Similar initiatives at the state level have already been established in Latin America in countries such as Mexico (Verificado; Magallón-Rosa, 2019), Brazil (Comprova), Argentina (Reverso), and Uruguay (Verificado). RedCheq was headed by Colombiacheck, a digital, open, and collaborative fact-checking platform signatory of the Code of Principles of the International Fact-Checking Network and Consejo de Redacción, a nonprofit organization that counts among its ranks more than 100 associated journalists in Colombia to foster research journalism and contribute to the democratization of information.

In Colombia, the exercise of the journalist profession suffered the consequences of the armed conflict. Cartografías de la información, conducted by Fundación para la Libertad de Prensa (2019), a nonprofit organization that defends press freedom and the practice of journalism, presents the following alarming conclusion: 578 out of the 994 analyzed municipalities correspond to silenced zones, i.e., places where there is no media outlet to produce local journalism, and $29 \%$ of the population resides in such places. Gentzkow, Shapiro, and Sinkinson (2011) stated that media outlets positively influence political participation, particularly when the first outlet is established.

A recent study on the working conditions in Colombian regional journalism (Valencia-Nieto, PereiraGonzález, \& Rodríguez-Leuro, 2019) that was based on 139 interviews depicts regional journalism as a poor trade where journalists are subjected to power pressures and disseminate official narratives; therefore, regional journalism is at its critical levels of credibility because it is unable to examine power thoroughly. Consequently, its contribution to democratic quality is insignificant.

Colombia had already experienced a disinformation context during the October 2nd, 2016 referendum on peace agreements. As Pablo Medina-Uribe (2018) recalls:

During the autumn of 2016, a prominent politician admitted having deliberately deceived the audience before one of the most important elections in the history of the country. By doing so, he confirmed what many citizens already knew: WhatsApp, a digital communication platform, which is now widely used, is a fertile ground for group manipulation.

Further, Colombiacheck and Consejo de Redacción guaranteed the regional journalists' training by organizing 10 workshops in Casanare, Santander, Cesar, Tolima, Caldas, and Valle del Cauca, among others, which ended in a Chequeatón in Bogota (August 13th and 14th, 2019), and established RedCheq. In addition, the fact-checking process was supervised, edited, and sponsored using the Colombiacheck methodology.

The methodological process implemented by RedCheq comprised six steps, namely, to select a phrase (content) from the public sphere due to its relevance and impact, to consult with the author of the phrase, to compare the information and data with official and reliable sources and then with alternative and expert sources, to contextualize the checking in terms of time and socioeconomic or political aspects, and to qualify the statement (true, slightly true, questionable, fake, or uncheckable).

Further, this study incorporates the Latin American context to fact-checking journalism studies through in-depth interviews of journalists within the network. As academic attention is mainly focused on the Englishspeaking countries, it is imperative for new approaches to be developed in order to define and compare the factchecking and disinformation systems (Hallin \& Mancini, 2004). Vázquez-Herrero, Vizoso, and López-García (2019) analyzed 135 fact-checking initiatives from across the world and concluded that most of the fact-checking platforms are European and American native digital media; they found that their regional coverage scope is only $9 \%$. At the beginning of May 2020, it was estimated that 237 teams devoted to fact-checking were active worldwide, with 26 teams in South America: Argentina (2), Bolivia (1), Brazil (10), Chile (2), Colombia (3), Ecuador (1), Peru (2), Uruguay (3), and Venezuela (2; Duke Reporters' Lab, 2020). Only 78 of these fact-checking journalistic organizations were signatories of the Code of Principles of the International Fact-checking Network.

\subsection{Colombian Political Context}

The first regional elections since the peace agreements with the Revolutionary Armed Forces of Colombia in 2016 were held on October 27th, 2019. According to the National Civil Registry Office's (2019) data, Colombians elected a total of 1,101 mayors, 32 governors, 12,063 city councilors, 418 representatives, and 6,814 elected officials. To this end, 3,306 elections were held to vote for local authorities. The main participation data revealed that $60.65 \%$, which equals 22,1 million of Colombians based on the census of 36,5 million people, exercised their right to vote in order to nominate their mayor. Participation in the election of the departmental governors was $61 \%$, with 18,8 million of votes being cast on the basis of a census of 30,8 million of Colombians.

The Electoral Observation Mission (2019) witnessed the progress made in the exercise of the right to votethanks to the "conclusive progress in terms of safety related to noninterference by the armed groups in the elections...civic engagement, electoral debate, and the results of authorities in chasing electoral crimes." However, this aspect does not conceal the irregularities detected during the previous months such as electoral transhumance or fraud committed on the election day.

Colombia conducted the regional elections in a political context marked by the tribulation and a crisis between the government and the governed, with the latter motivated by the lack of integrity and efficiency of public management. The political culture sur- 
vey conducted between July and August in 2019 by the National Statistics Office revealed that $80.7 \%$ of Colombians consider living in a democracy to be very important, but $47.1 \%$ exhibited profound dissatisfaction with its functioning. In the Colombian political context, corruption is one of the main reasons for strife in the country. Municipal governments are perceived to be corrupt or very corrupt by $61.2 \%$, and a very similar percentage is obtained for the departmental governments (60.4\%). However, both these percentages are less than the percentage obtained for the national government (64\%). These percentages reflect a major concern regarding the political system because a setback can be observed between 2017 and 2019 in the urban population, which demonstrates robust confidence in city halls $(-4.5 \%)$, governance $(-8.8 \%)$, and departmental assemblies (-2\%; National Statistics Office, 2019).

\section{Literature Review}

After the Brexit electoral processes, the Colombian referendum, and the US presidential elections in 2016, there is no doubt that disinformation strategies are effective and may imperil the prospects of democracy in any country of the world. Moreover, fake news is not a new phenomenon; it has always existed. However, the current situation fosters a higher global scope and impact because the media, through which the fake news is disseminated, and the speed of dissemination also favor it (Burkhardt, 2017). Focused on the political disinformation, Valenzuela, Halpern, Katz, and Miranda (2019) stated that political commitment is an important consequence of news consumption through social networks and that it entails a key precedent when it comes to sharing fake news. Therefore, disinformation emerges as a problem for democracies, particularly during the electoral times and referendums (European Commission, 2018; Newman, Fletcher, Kalogeropoulos, \& Kleis-Nielsen, 2019).

Fregoso (2018) states that, with the peak of independent digital media, several readers have begun to doubt the quality and impartiality of the information being published through newspapers; however, for millions of new young readers, the printed information seems to be no longer relevant. New technologies have modified the social behaviors related to producing and consuming information within the field of journalism because the changes related to the digitalization of communication outlets and the dissemination of erroneous information challenge the social role and authority of journalism (Ekström, Lewis, \& Westlund, 2020). These changes and the information obesity in social media need to be examined to understand the relationship between the use of news and trust in news (Kalogeropoulos, Suiter, \& Eisenegger, 2019). This aspect broadens the horizon to determine the factors that aid or inhibit resilience in the society regarding the disinformation phenomenon (Humprecht, Esser, \& Van Aelst, 2020).
The academic literature has offered several approaches and classifications for disinformation and related concepts such as misinformation and fake news. Fake news has become a catch-all, buzzword, or mainstream word to include all misleading information. Tandoc, Lim, and Ling (2018), based on a review of how previous studies had operationalized the term fake news, identified two dimensions (facticity and deception) and they established six types of fake news: news satire, news parody, fabrication, manipulation, advertising, and propaganda. In the same line, but through contrasting the concept of fake news with real news, Molina, Sundar, Le, and Lee (2019) identified seven types of fake news: false news, polarized content, satire, misreporting, commentary, persuasive information, and citizen journalism. There is a debate about the inclusion or exclusion of the satire content as a typology of disinformation due to a satire content which does not have a deceitful intention to mislead, although may exert the function of misleading (Fallis, 2015; Molina et al., 2019; Tandoc et al., 2018).

However, some authors are avoiding the usage of the term fake news to define the information pollution phenomenon. The contention lies on the epistemology and the better accuracy of disinformation to refer to the information disorder. Fake news does not hold an ordinary public meaning. For instance, its linguistic deficiency, its media delegitimizing meaning and the political propaganda that surrounds it, and the variety of different informative content that not always imitating the aesthetic of news content (Estrada-Cuzcano, Alfaro-Mendives, \& Saavedra-Vásquez, 2020; Habgood-Coote, 2019; Rodríguez-Pérez, 2019; Wardle \& Derakhshan, 2017; among others). Specifically, fake news is currently a weaponizing term that favors polarization when politicians mention news content that refutes a partisan position, eroding the credibility and trust in news media. In the recent research within the journalism practice, Egelhofer, Aaldering, Eberl, Galyga, and Lecheler (2020) found in Austrian news reporting that the buzzword fake news is associated more often with attacks on legitimate news media and less with the threat of online disinformation.

On the other hand, Wardle and Derakhshan (2017) explained the information disorder which is based on falseness and harmful factors. There are three environments that are distinguished, namely: misinformation, disinformation, and mal-information. Misinformation refers to false information without a harmful intention; disinformation is false information shared to cause harm; and mal-information is genuine information shared to cause harm. The difference between misinformation and disinformation states if there is an active and intentional attempt to mislead (Fallis, 2015). For instance, Fetzer (2004, p. 231) defines misinformation as "false, mistaken, or misleading information" and disinformation as "distribution, assertion, or dissemination of false, mistaken, or misleading information in an intentional, deliberate, or purposeful effort to mislead, deceive, or confuse." 
In this context, fact-checking journalism is shaped as a new practice to fight disinformation or as an emerging journalistic genre (Graves, 2018). Fact-checking objectives is not to address electoral-voting behavior because a political actor has deliberately and repeatedly lied; instead, one of its objectives is to enable citizens to exercise their right to vote with the most verified information possible and within a public sphere that is uncontaminated by propaganda and disinformation strategies, which are extremely sensitive to emotional appeal and polarized scenarios.

Researchers investigating fact-checking have analyzed the need for news checkers to consolidate within the media ecosystem and gain the audience's trust (Humprecht, 2019; Lowrey, 2017), the journalists' perception and practices (Cheruiyot \& Ferrer-Conill, 2018; Graves, 2017; Mena, 2019), and the effectiveness and social effects of fact-checks (Walter, Cohen, Holbert, \& Morag, 2019). Moreover, journalists concur on pointing out the normative aspects of fact-checking and the need for clear methodological guidelines and boundaries between fact-checking and activism because factchecking should be unbiased (Mena, 2019). For these purposes, an epistemological debate prevails between the preconceived political judgments of fact-checkers and their common access to the objective truth (Uscinski, 2015). However, supported by empirical quantification, Amazeen (2015) exhibited a high level of consistency in fact-verification and concluded that fact-checking journalism has a crucial role to play in fighting disinformation.

\section{Objectives and Method}

Fact-checking journalism is emerging as a journalistic practice to fight disinformation. Centered around Colombia, RedCheq was established as the first crossregional alliance to fight disinformation related to regional elections. Therefore, factors such as RedCheq's achievements, its journalistic works, and competencies that are considered necessary for fact-checking by the regional journalists should be explored. Given below are the three specific objectives of this study: (1) Through the regional journalists' viewpoints, analyze how factchecking journalism is useful in the regional political contexts; (2) highlight the achievements by RedCheq as an alliance to fight political disinformation in the regional elections and its contribution to Colombian society and journalism; and (3) identify the requirements and necessary competencies in regional journalism for the practice of fact-checking journalism.

Further, in-depth interviews provide a complete analytical understanding in order to acquire a specific viewpoint as well as providing a reasoned opinion of the individual work of the regional fact-checking journalists, the operations of RedCheq, and the characterization of disinformation that was disseminated in Colombia during the regional elections. First, we obtained the local journalist sample from the database of Colombiacheck, a fact-checking media and leader of the project. Then, we assessed the available information provided by classifying journalists according to those who worked freelance and those who were affiliated with regional media outlets. In these latter cases, we interviewed the team leader, who is the designated journalist in charge of fact-checking news developed by the regional media outlet. We interviewed all freelance journalists and team leaders affiliated to local media that participated in RedCheq based on data provided. In all, 11 in-depth interviews, using structured questionnaires through digital communication applications such as Google Meet and WhatsApp, were conducted to the regional journalists who were a part of RedCheq in April 2020 (see Table 1). 7 out of 11 interviewees worked in local media outlets such as print, digital-native, television and radio station located in Antioquia, Casanare, La Guajira, Risaralda, Santander, and Valle del Cauca. 4 out of 11 worked as freelance journalists or were associated with Universities of Caldas, Caquetá, Tolima, and Valle del Cauca. Consequently, and supported by Colombiacheck's headquarter in Bogotá, the regional fact-checking network was in nine Colombian' departments listed as follows: Antioquia, Caldas, Caquetá, Casanare, La Guajira, Risaralda, Santander, Tolima, and Valle del Cauca. This instrument enables to gather, in orderly fashion, the different individual characteristics emphasized by the interviewees and identify patterns through which to deduce the most noticeable trends based on the compared analysis of each one of them can be deduced.

The questionnaire included some control variables (i.e., geographical location, years of professional experience, and first experience as a fact-checker) plus 13 questions divided into three main parts according to our specific research objectives. The first row of questions was about political disinformation in Colombia, its characteristics, and the influence in the electoral context. The second row of questions asked about methods, purposes, and skills to become a fact-checker. Lastly, we asked for a general assessment and further steps for RedCheq. We recorded the interviews using artificial intelligence applications and a proof-reading review was carried out to match the transcription with the statements. We collected all the answer into a single document from which we made comparisons, identified the patterns, and deduced the most relevant arguments according to our specific research objectives.

Questions are listed as follows: (1) How would you describe the disinformation disseminated during the Colombian regional elections? (2) How particularly would you describe your fact-checking work in your regional area? (3) Which reasons motivated you to develop fact-checking journalism? (4) Working as a factchecker, what was your purpose as a RedCheq journalist? (5) Do you consider, after participating in RedCheq, that your work as a fact-checker allowed obtaining a higher recognition from peers? (6) Considering all disinforma- 
Table 1. List of interviewees.

\begin{tabular}{|c|c|c|c|}
\hline Interviewee ID & Date of interview & $\begin{array}{l}\text { Years of professional } \\
\text { experience }\end{array}$ & First experience as a fact-checker \\
\hline$A$ & April 1st, 2020 & 19 & Yes \\
\hline B & April 1st, 2020 & 3 & Yes \\
\hline C & April 4th, 2020 & 12 & Yes \\
\hline $\mathrm{D}$ & April 6th, 2020 & 12 & Yes \\
\hline $\mathrm{E}$ & April 7,th 2020 & 2 & $\begin{array}{l}\text { No, previously associated with Colombiacheck during } \\
\text { the national elections (2018) }\end{array}$ \\
\hline $\mathrm{F}$ & April 8th, 2020 & 18 & Yes \\
\hline G & April 10th, 2020 & 5 & $\begin{array}{l}\text { No, previously associated with Colombiacheck during } \\
\text { the national elections (2018) }\end{array}$ \\
\hline $\mathrm{H}$ & April 13th, 2020 & 4 & Yes \\
\hline 1 & April 20th, 2020 & 21 & $\begin{array}{l}\text { No, previously involved in the fact-checking practices } \\
\text { within the nonaccredited fact-checking media }\end{array}$ \\
\hline J & April 20th, 2020 & 6 & $\begin{array}{l}\text { No, previously associated with Colombiacheck during } \\
\text { the national elections (2018) }\end{array}$ \\
\hline K & April 25th, 2020 & 10 & Yes \\
\hline
\end{tabular}

tion contents, what do you consider that has the worst effects on citizens? (7) From your point of view, does the fact-checker prioritize the scrutiny of public discourse, debunks viral disinformation contents or a balance of both? (8) Did you notice your work as a fact-checker at RedCheq contributed to achieving a better public debate? (9) Which criteria did you follow to decide which contents would select for verification? (10) Do you consider your work at RedCheq was free of political interests, social activism or economic pressures? (11) How do you evaluate your skills for developing fact-checking? (12) Do you think RedCheq achieved its goal of debunking disinformation associated with the regional election that took place in October 2019? (13) If you had to repeat the crossregional network, what would you change? What would you improve?

\section{Results}

\subsection{Achievements}

Regional journalists unanimously state that RedCheq fulfilled the objective of fighting disinformation and monitoring the public discourse and malicious use of political information. Their reasons are based on the impact caused by the work on political discourse and public debate. The regional fact-checkers linked the prominent political disinformation to misleading and manipulating strategies, which then polarized and attacked other political candidates. They explained the danger caused by disinformation when these misleading contents influenced or modified citizens' political behavior. Their arguments mentioned the refusal against citizens involved in peace agreements, panic scenarios, and the delegitimization of politicians, among others. This also increased the risk of
WhatsApp chains and how much people trusted in the news they had received on their smartphones.

They perceived that their work was based on the exercise of media literacy related to fact-checking processes in order to develop critical thinking competence in citizens. The study finding demonstrates that regional journalists emphasize that RedCheq contributed toward revealing topics silenced in the media outlets because "several contents were extracted from areas where traditional media was reluctant to enter" (Interviewee J). Furthermore, "RedCheq caused an impact at the national level; even the controlled organizations themselves began to replicate and worked with much input from the network" (Interviewee K). They perceived that the factchecking exercise contributed toward improving the status and credibility of regional media because it informed about the political and electoral affairs by exercising an oversight counterpower regarding election process guarantees and producing electoral costs when the associated contents were verified to be inaccurate:

This contributed to the extent that public figures or candidates were obliged to be more careful with their discourse when we performed the fact-checks. Toward the end of the campaign, the discourse was more moderate and that is a part of the contribution made by RedCheq. (Interviewee A)

In addition, the exercise of fact-checking fostered the critical spirit of citizens by providing arguments and data for debates: "Readers used to send e-mails or notifications for us to verify. The debate and desire to debunk fake news were present in that minority audience" (Interviewee B). Articulation and collaboration by fact-checkers and citizens create a renewed process 
of citizen journalism (Rodríguez-Pérez, 2020), which, in addition, enables "people to become aware of the seriousness of replicating information that is not verified" (Interviewee E). Consequently, this aspect generates increased prudence and skepticism regarding the information received through social media or instant messaging applications: "People tried to be frugal when receiving those speeches and not to believe everything they heard or read, and even this was important as it ratified that what they were saying was real" (Interviewee F).

Therefore, the interviewees' opinions highlight the importance of fact-checking within the citizens' social concerns about distinguishing between what is real and what is fake and answering this need by empowering them through training and arguments:

The exercise not only involves checking but also examining the manner in which the media contributes to public education and the process by which the public can begin to learn to identify this type of publication themselves so as not to share it, thereby reducing such dissemination. (Interviewee C)

Checking not only involves debunking or revealing the truth but also showing the citizens the elements that are potentially available to them to build autonomy and critical thinking about each leader and public figure, thus providing them with the tools required in order to be involved in the public discourse. (Interviewee G)

For such purposes, the regional journalists consider that fact-checking should be addressed as a majority bet on the Colombian media system. Moreover, they underscore the precedent of this network as a seedbed that will have a national impact:

I believe that all media outlets should focus on how they train journalists in fact-checking. I think that people, i.e., public opinion, are deliberately asking for this. The media cannot turn a blind eye to this issue. (Interviewee C)

RedCheq set a precedent for this type of journalism in our country. It is a seedbed, and if we foster journalists' training in news verification further, this will positively establish the journalism dynamic at the national level. (Interviewee K)

The in-depth interviews exhibit a significant relationship between the exercises developed with media literacy and university training. In particular, one of the regional media that are associated with RedCheq operated as a teaching media outlet and capitalized on the factchecking practices to instill social values among young people. Another regional journalist instilled these values from the university sphere:
Our news program is a school. In a context where everyone is a content producer, we also forget a very important value, which is important not only for a journalist but also for a citizen: rigor. (Interviewee K)

I wanted to pass that passion for truth to students and wanted them to understand that this is not just about picking a piece of information and saying whether it is true or false but about an amazing passion for truth that is, basically, journalism. (Interviewee G)

\subsection{Skills and Training}

Most of the interviewees rate their competencies in factchecking as sufficient or good, although all of them associate the verification process with the ongoing learning that requires constant training. One of the interviewees defined RedCheq as a "network to train journalists" (Interviewee K). The interviewees emphasize that factchecking journalism, as a new practice, requires constant training so that journalists can be better equipped to fight disinformation and enhance their knowledge through their experiences:

Platforms change at the same pace as tools to produce fake news. So, what was clearly required to be checked today or yesterday can change tomorrow in such a disguised manner that it may even go unnoticed. (Interviewee J)

This is an ongoing learning exercise. We are capable and willing to do it, but, perhaps, we need to know ways to access information to continue our training and the contexts in which we have to keep on applying this. I would like to have more space for fact-checking training because I think all journalists should be able to do it. (Interviewee K)

The main limitation that the interviewees expressed is related to the competencies in the use of digital tools for checking videos or photographs (multimedia formats):

There are technical aspects that we would like to know more about; for example, ways to identify whether a video is fake or whether the photographs have been manipulated. On a 1-to-10 scale, we score 6-7. (Interviewee C)

We have a long way to go. New tools have been launched, and we have to keep ourselves updated. I have been using $70 \%$ of the capacity I have until now. However, we also need the remainder percentage to consider the integrity and protection of journalists. (Interviewee A)

The interviewees state that knowledge acquired through daily practice is another aspect to conduct a successful check; they emphasize that it is an aspect that 
is key to develop a journalistic instinct in order to detect disinformation:

Fact-checking is something new, and because it is a relatively new trend, it is something that we have no experience in at the time of performing it. Besides, this requires that for every refuted piece of news something must be learned on the subject. (Interviewee B)

Competencies are good, but there is a possibility to improve them continuously. There are some things in which I think I am more competent in than others are (altered images, context of publications, and data and hiring documents). There are other qualifications that I think I can continue to improve such as developing a journalistic instinct so as not to take some things for granted. (Interviewee E)

After the training workshops and the fact-checking practice by RedCheq, most of the interviewees stated a perceived professional recognition from their peers and citizens. The journalistic value of fact-checkers becomes a "lighthouse" (Interviewee A) against the concern on disinformation. It continued after the regional elections when peers and citizens asked for checking contents disseminated in social media. However, and most importantly, they pointed out that fact-checking changed their professional practice, making them more prone to innovation in their newsrooms. They commented on these improvements regarding the use of digital tools, new procedures, and narrative recourses to produce journalism as well as the prevailing ethical standards to assure the accuracy of their own news production.

\subsection{Method}

RedCheq's methodology was the same implemented by Colombiacheck as interviewees recognized it. The content selection had to verify the political information in its core. From the answers, we identified three main selection criteria elements: (1) The monitoring of leading candidates according to polls; (2) electoral debates and the public discourse; and (3) the category of viral in social media contents to avoid the Streisand effect because of the fact-checking process. Furthermore, the interviewees reckon mostly (10 out of 11 ) the fact-checker should have to balance the scrutiny of public discourse with the verification of viral contents:

A political discourse that states against certain democratic value is as dangerous as fake content that becomes viral. The viral content requires to be checked faster, but both should be balanced. (Interviewee $\mathrm{H}$ )

Both bot farming and fake users are a common practice among political parties that use the social networks for amplifying a political message. (Interviewee A)

The dilemma emerged when the interviewees decided about the political statement to be checked. Their answers allow identifying a fear to be perceived as partisan, reported by readers. The political polarization context, as well as the strength or weakness of certain political candidates emerged as the causes that tipped the balance on one political side:

I felt like it was a problem that others thought that I had political bias, especially if the fact-check made a candidate looks better. (Interview F)

We wanted to have an equilibrium producing factchecks in the political spectrum, but we understood that was something we could not force. If a certain candidate did not say anything checkable or there was not anything about a certain candidate because it was not a leading candidate, we could not produce a factcheck. (Interviewee C)

If we produced ten fact-checks, probably five assessed a misleading against the ex-president Álvaro Uribe's political leaning and the rest distributed among the other parties. Political sphere surrounding Uribe's political party generated disinformation; it was also one of the most mediated and robust electoral campaigns. (Interviewee A)

Besides, one of the boundaries established around factchecking is the non-partisan practice and the clear distinction between fact-checking and activism. Asking for political and economic pressure as well as social activism, some interviewees declared Colombiacheck editorial board promoted press freedom assuring the non-partisan filter. The economic pressure did not reveal, although one of the interviewees said when they assessed a claim as inaccuracy the advertising from that campaign was reduced. Political pressure happened when candidates were checked:

There were pressures when the content was close to elites. When a journalist began to ask, the answer suggested not disseminating it....The process is threatened. That also occurs from activism when after producing a fact-check, activists encouraged you finding more false claims. (Interviewee D)

We felt the higher pressure came from political campaigns. For instance, they said: "You are publishing a lot about us, why do you not assess what others say against us?" (Interviewee C)

On the other hand, other interviewees with less professional experience (Interviewees B, E, and H) admitted what they call "social activism" during their reporting. 
They associated this commitment with improving the public debate, understanding that debunking disinformation protected the democratic good of fair elections.

\subsection{A Way Forward}

The interviewees qualified the coordination and supplementary works of Colombacheck during the whole process as "good" (Interviewee J), "wonderful" (Interview K), or "titanic" (Interviewee C). On the basis of these perceptions, most of the interviewees agree that training is a factor that is particularly vital toward improving an initiative such as this one. To this end, two alternatives are suggested: "Monitoring" (Interviewee K) or "customized accompaniment" (Interviewee J) to improve the quality and quantity of checks, respectively, and "to continue with the trainings on different tools" (Interviewee E).

In addition, and in accordance with the abovementioned viewpoints, journalists agree that the lack of experience and competencies in using fact-checking digital tools led to the delays in the checking process: "Colombiacheck has the experience and training, but issues still remain with regard to optimizing the process and having trained people in the regions so as not to centralize everything in people with technical abilities" (Interviewee C).

RedCheq's internal process included the first proposal shared by the regions with Colombiacheck's national coordination unit or Colombiacheck with regional journalists. After receiving feedback regarding the suggested drafts and specific requests for verification of multimedia content submitted by the regions to Colombiacheck, the fact-check was written down and then reviewed by the Colombiacheck editors to make adjustments or proceed with its posting on the Web. Given that Colombiacheck headed RedCheq, the regional verification network included the seal of the International Fact-checking Network, making it obligatory for them to check on and comply with the international fact-checking methodological process standard.

Therefore, the interviewees perceive the "flow" (Interviewee D), the "internal process speed" (Interviewee F), or the articulation of "the production chain between the journalist performing the check, the editor, and the final piece of news" (Interviewee $\mathrm{H}$ ) as areas of improvement. Moreover, the only suggestion provided to make up for this aspect is to improve the regional journalists' training.

One of the challenges faced by fact-checking is to try and balance the reach and dissemination of disinformation (Vosoughi, Roy, \& Aral, 2018) by answering rapidly and "reducing the time between the release of disinformation and the publication of the check" (Interviewee C). With regard to this, as a third aspect, the interviewees highlight the need for "dissemination improvement" (Interviewee I). They suggest innovation as a solution, along with new narratives that are based on multimedia formats and social network and Web environment strategies:

Disinformation could actually be mitigated, but this failed to reach a larger audience or to equal the fake news that was disseminated....To remedy this situation, I would suggest a community manager strategy or something that helps better the position of the website. (Interviewee B)

I feel that we stick inordinately to the text. The process would be much more dynamic if journalists were trained in the creation of verification content in several formats. They began producing podcasts, but I think we need to be quicker in data visualization and the creation of audiovisual, as well as interactive content. (Interviewee E)

Correspondingly, they suggest that RedCheq should incorporate more media and journalists to cover more municipalities and departments of the country:

Regional journalists' contribution is important. There are things happening in the other area of Colombia, and it seems like they have been taken out of a science fiction book. Here, we see things that a person living in Bogota cannot even imagine actually happen in the country. (Interviewee A)

It would have been wonderful to have a responsible from RedCheq present in those municipalities to monitor the public debate underway in the face of elections in that territory. (Interviewee G)

Finally, only one of the interviewees stated the need to modify the verification categories by "making factchecking more expedited" (Interviewee A) to improve citizens' understanding.

\section{Discussion and Conclusions}

The zenith of disinformation involves rethinking the news production routines and ways to disseminate journalistic information effectively. As distrust of media outlets and politics prevails in Colombia, finding certain evidence that associates less trust in the news and politics with a higher probability of believing in online disinformation was initiated (Zimmermann \& Kohring, 2020).

RedCheq emerged as a collaborative experience, headed by Colombiacheck, for debunking the spread of false political information in the regional areas. This need cannot be addressed without considering the social, labor-related, and economic contexts of the Colombian regional media outlets. While disinformation easily reaches mobile devices, verified and checked information requires the participation of information professionals. This aspect entails their being present and procuring training and independence to conduct good journalism. 
This context contrasts with the perceptions of the regional journalists who were interviewed in this study after working for RedCheq. They perceive the factchecking practice as a wake-up call to modify the performance of regional journalism. The 11 regional journalists who were interviewed agree on underscoring the work conducted by RedCheq to oversee power and make a thorough public examination of the electoral campaign statements. A widespread perception about RedCheq exists in that its reputation precedes it regarding its contribution to improve informed public debate by offering contrasted and unbiased information. However, such improvements were limited regarding scope and regional application. RedCheq was thus shaped as a seedbed for the introduction of fact-checking as a novel journalistic practice in regional journalism.

In summary, the practice of fact-checking journalism by RedCheq has dared to address the following three cleavages. It restores credibility to regional journalism performance by contrasting facts and data in an unbiased and rigorous manner; it contributes to the democratic training of public opinion, which is empowered with contrasted information; and it encourages power auditing. In the political and electoral contexts, journalistic coverage is a key driver of electoral accountability (Snyder \& Strömberg, 2008) and the political participation (Gentzkow et al., 2011). A well-informed and mobilized electorate better regulates government corruption and mismanagement practices (Adsera, Boix, \& Payne, 2003). Finally, journalism is crucial for civic engagement (Shaker, 2014).

Regarding the professional recognition after completion of RedCheq, Colombian journalists' perceptions coincide with the argument of Graves, Nyhan, and Reifler (2016) that fact-checkers receive recognition and status as upholding the ideals of the profession. On the other hand, our results are slightly different from Mena's results (2019) regarding the perceptions of the regional fact-checkers towards the principal purpose of the factchecking practice. In contrast to US fact-checkers who prioritized the assessment of statements by public figures and institutions (91.8\% strongly agree rather than $57,4 \%$ strongly agree with debunking false news stories spread on social media), Colombian fact-checkers affirmed it should be balanced between politicians' statements and viral contents. Moreover, this case study reflects one of the epistemological dilemmas of fact-checking: the boundaries between fact-checking and activism.

Moreover, disinformation, as a worldwide phenomenon, and fact-checking journalism, as a journalistic answer, reveals the need to create a new map of competencies, profiles, and trends. This aspect entails curricular strengthening and an innovative development of the profession. Academicians and communication media are becoming aware of fact-checking journalism as a quality assurance practice and a duty in exercising the profession, thereby necessitating learning new competencies (Ufarte-Ruiz, Peralta-García, \& Murcia-Verdú, 2018).
Therefore, it is appropriate to facilitate the acquisition of university knowledge to provide aspiring journalists with new professional opportunities available at small media outlets, which are more independent, diverse, and committed to professional, social, and ethical values. Furthermore, universities should update their curricula to integrate these competencies into digital tools. This aspect would enable aspiring journalists to learn digital forensics techniques to analyze the accuracy of each source of information-from multimedia formats to public statements (Steensen, 2018)-and debunk disinformation content, particularly at a time when an emerging media ecosystem sponsored by fact-checking journalism is envisaged in Latin America to achieve a real media democracy (Palau-Sampio, 2018).

These differential competencies may lead to the creation of new media outlets and the revitalization of the media sector, given the growing civic concern to distinguish between what is true and what is fake. Furthermore, universities may use this opportunity to strengthen their associations with the business sector and civil society by becoming involved in the verification projects, which have been very closely related to the academic environment (Graves \& Cherubini, 2016).

To conclude, RedCheq is the first regional factchecking alliance, a network of regional newsrooms and freelance journalists engaged in delivering factchecking journalism within the electoral contexts. To this end, a new set of news practices was formulated and established to deliver accountable journalistic practices that offer high quality fact-checks to regional citizens. Based on the journalists' perceptions, we summarize the fact-checking practice experience and training that are the key determinants in making a successful practice out of fact-checking journalism. Regional journalists regard fact-checking as a demanding journalistic practice. Therefore, expertise and technical skills are required to debunk political disinformation, thus increasing the fact-checks' coverage and dissemination and reducing the gap between the disinformation content that becomes viral and the fact-check releases. Moreover, the fact-checking movement should reinforce its scope and broaden its horizons to go beyond the main cities and into new geographical areas. To this end and for the purpose of advancing and reinforcing the fact-checking processes in the regional areas, upgrading journalism and communication networks might be the most suitable way of guaranteeing the acquisition of media competencies by aspiring journalists. All of these factors are aimed at integrating the verification operations in any journalistic process irrespective of the media outlet, geographic location, or content.

Thus, in the context of social and political polarization, along with weak regional journalism that depends on the political, economic, or social powers, regional journalists perceived fact-checking as a catalyst for the awakening of the regional journalism and as a reconnection with the journalist's social responsibility to foster 
civic empowerment and to subject political discourse in the electoral campaigns to rigorous examination.

\section{Acknowledgments}

This work was supported by the project 'Knocking down fakes news: Analysing Fact-checking journalism processes and effects,' financed by the Universidad de Ibagué (Tolima, Colombia). Project code: 20-011-INT.

\section{Conflict of Interests}

The authors declare no conflict of interests.

\section{References}

Adsera, A., Boix, C., \& Payne, M. (2003). Are you being served? Political accountability and quality of government. The Journal of Law, Economics, and Organization, 19(2), 445-490. https://doi.org/10.1093/jleo/ ewg017

Amazeen, M. A. (2015). Revisiting the epistemology of fact-checking. Critical Review, 27(1), 1-22. https:// doi.org/10.1080/08913811.2014.993890

Burkhardt, J. M. (2017). Combating fake news in the digital age. Library Technology Reports, 53(8), 1-33. https://doi.org/10.5860/Itr.53n8

Cheruiyot, D., \& Ferrer-Conill, R. (2018). Fact-checking Africa. Digital Journalism, 6(8), 964-975. https://doi. org/10.1080/21670811.2018.1493940

Duke Reporters' Lab. (2020). Update: 237 fact-checkers in nearly 80 countries...and counting. Reporterslab. Retrieved from https://reporterslab.org/category/ fact-checking

Egelhofer, J. L., Aaldering, L., Eberl, J., Galyga, S., \& Lecheler, S. (2020). From novelty to normalization? How journalists use the term "Fake news" in their reporting. Journalism Studies. https://doi.org/ 10.1080/1461670X.2020.1745667

Ekström, M., Lewis, S. C., \& Westlund, O. (2020). Epistemologies of digital journalism and the study of misinformation. New Media and Society, 22(2), 205-212. https://doi.org/10.1177/1461444819856914

Electoral Observation Mission. (2019). Informe de cierre de la misión de observación electoral MOE [Final report of Election Observation Mission (MOE)]. MOE. Retrieved from https://bit.ly/3jn5r9p

Estrada-Cuzcano, A., Alfaro-Mendives, K., \& SaavedraVásquez, V. (2020). Disinformation y misinformation, posverdad y fake news: Precisiones conceptuales, diferencias, similitudes y yuxtaposiciones [Disinformation and misinformation, post-truth and fake news: Conceptual precisions, differences, similarities and juxtapositions]. Información, Cultura Y Sociedad, 42, 93-106. https://doi.org/10.34096/ics.i42.7427

European Commission. (2018). Flash Eurobarometer 464: Fake news and disinformation online. Brussels: European Commission. Retrieved from https://bit.ly/
3jrAYHb

Fallis, D. (2015). What is disinformation? Library Trends, 63(3), 401-426. https://doi.org/10.1353/lib. 2015.0014

Fetzer, J. H. (2004). Information: Does it have to be true? Minds and Machines, 14(2), 223-229. https:// doi.org/10.1023/b:mind.0000021682.61365.56

Fregoso, J. (2018). \#Mexico2018/'fake news' and social media: The new heads of the Hydra. Oxford: Reuters Institute for the Study of Journalism. Retrieved from https://bit.ly/3b80ixp

Fundación para la Libertad de Prensa. (2019). Cartografías de la información [Information cartographies]. FLIP. Retrieved from https://bit.ly/34FcvKq

Gentzkow, M., Shapiro, J., \& Sinkinson, M. (2011). The effect of newspaper entry and exit on electoral politics. American Economic Review, 101(7), 2980-3018. https://doi.org/10.1257/aer.101.7.2980

Graves, L. (2017). Anatomy of a fact check: Objective practice and the contested epistemology of fact checking. Communication, Culture \& Critique, 10(3), 518-537. https://doi.org/10.1111/cccr.12163

Graves, L. (2018). Boundaries not drawn. Journalism Studies, 19(5), 613-631. https://doi.org/10.1080/ 1461670x.2016.1196602

Graves, L., \& Cherubini, F. (2016). The rise of factchecking sites in Europe. Oxford: Reuters Institute for the Study of Journalism.

Graves, L., Nyhan, B., \& Reifler, J. (2016). Understanding innovations in journalistic practice: A field experiment examining motivations for fact-checking. Journal of Communication, 66(1), 102-138. https://doi. org/10.1111/jcom.12198

Habgood-Coote, J. (2019). Stop talking about fake news! Inquiry, 62(9/10), 1033-1065. https://doi.org/ 10.1080/0020174X.2018.1508363

Hallin, D. C., \& Mancini, P. (2004). Comparing media systems: Three models of media and politics. Cambridge: Cambridge University Press.

Humprecht, E. (2019). How do they debunk "fake news"? A cross-national comparison of transparency in fact checks. Digital Journalism, 8(3), 310-327. https://doi. org/10.1080/21670811.2019.1691031

Humprecht, E., Esser, F., \& Van Aelst, P. (2020). Resilience to online disinformation: A framework for crossnational comparative research. The International Journal of Press/Politics, 25(3), 493-516. https://doi. org/10.1177/1940161219900126

Kalogeropoulos, A., Suiter, J., \& Eisenegger, M. (2019). News media trust and news consumption: Factors related to trust in news in 35 countries. International Journal of Communication, 13, 3672-3693.

Lowrey, W. (2017). The emergence and development of news factchecking sites. Journalism Studies, 18(3), 376-394. https://doi.org/10.1080/1461670X. 2015.1052537

Magallón-Rosa, R. (2019). Verificado México 2018: Desinformación y fact-checking en campaña electoral 
[Verificado Mexico 201: Disinformation and factchecking on electoral campaign]. Revista De Comunicación, 18(1), 234-258. http://doi.org/10.26441/ RC18.1-2019-A12

Medina-Uribe, P. (2018). In Colombia, a WhatsApp campaign against Posverdad. The Wilson Quarterly. Retrieved from https://www.wilsonquarterly.com/ quarterly/the-disinformation-age/in-colombia-awhatsapp-campaign-against-posverdad

Mena, P. (2019). Principles and boundaries of factchecking: Journalists' perceptions. Journalism Practice, 13(6), 657-672. https://doi.org/10.1080/ 17512786.2018.1547655

Molina, M. D., Sundar, S. S., Le, T., \& Lee, D. (2019). “Fake news" is not simply false information: A concept explication and taxonomy of online content. American Behavioral Scientist. https://doi.org/10.1177/ 0002764219878224

National Civil Registry Office. (2019). Autoridades territoriales 2019 [Regional/local authorities 2019]. National Civil Registry Office. Retrieved from https://bit.ly/ 34L4LX6

National Statistics Office. (2019). Encuesta de cultura política (ECP) [Political culture survey (ECP)]. DANE. Retrieved from https://www.dane.gov.co/ index.php/comunicados-y-boletines/estadisticassociales/cultura-politica

Newman, N., Fletcher, R., Kalogeropoulos, A., \& KleisNielsen, R. (2019). Digital news report 2019. Oxford: Reuters Institute for the Study of Journalism.

Palau-Sampio, D. (2018). Fact-checking and scrutiny of power: Supervision of public discourses in new media platforms from Latin America. Communication \& Society, 31(3), 347-365. https://doi.org/10.15581/ 003.31.3.347-363

Rodríguez-Pérez, C. (2019). No diga fake news, di desinformación: Una revisión sobre el fenómeno de las noticias falsas y sus implicaciones [Do not say fake news, say disinformation: A review article about the fake news phenomenon and its implications]. Comunicación, 40, 65-74. https://doi.org/10.18566/ comunica.n40.a05

Rodríguez-Pérez, C. (2020). Una reflexión sobre la epistemología del fact-checking journalism: Retos $y$ dilemas [A reflection on the epistemology of fact-checking journalism: Challenges and dilemmas]. Revista de Comunicación, 19(1), 243-258. https:// doi.org/10.26441/rc19.1-2020-a14

Shaker, L. (2014). Dead newspapers and citizens' civic engagement. Political Communication, 31(1), 131-148. https://doi.org/10.1080/10584609.2012. 762817

Snyder, J., \& Strömberg, D. (2008). Press coverage and political accountability. Journal of Political Economy, 118(2), 355-408. https://doi.org/10.1086/652903

Steensen, S. (2018). Journalism's epistemic crisis and its solution: Disinformation, datafication and source criticism. Journalism, 20(1), 185-189. https://doi.org/

\section{$10.1177 / 1464884918809271$}

Tandoc, E. C., Jr., Lim, Z. W., \& Ling, R. (2018). Defining "fake news": A typology of scholarly definitions. Digital Journalism, 6(2), 137-153. https://doi.org/ 10.1080/21670811.2017.1360143

Tenove, C. (2020). Protecting democracy from disinformation: Normative threats and policy responses. The International Journal of Press/Politics, 25(3), 517-537. https://doi.org/10.1177/1940161220918 740

Ufarte-Ruiz, M., Peralta-García, L., \& Murcia-Verdú, F. (2018). Fact checking: Un nuevo desafío del periodismo [Fact checking: A new challenge in journalism]. El Profesional De La Información, 27(4), 733-741. https://doi.org/10.3145/epi.2018.jul.02

Uscinski, J. E. (2015). The epistemology of fact checking (is still naive): Rejoinder to amazeen. Critical Review, 27(2), 243-252. https://doi.org/10.1080/08913811. 2015.1055892

Valencia-Nieto, D. G., Pereira-González, J. M., \& Rodríguez-Leuro, J. A. (2019). Condiciones laborales y sociales de los periodistas en las regiones de Colombia [Labor and social conditions of journalists in the regions of Colombia]. Mediaciones Sociales, 18, 85-105. https://doi.org/10.5209/meso.66907

Valenzuela, S., Halpern, D., Katz, J. E., \& Miranda, J. P. (2019). The paradox of participation versus misinformation: Social media, political engagement, and the spread of misinformation. Digital Journalism, 7(6), 802-823. https://doi.org/10.1080/21670811. 2019.1623701

Vázquez-Herrero, J., Vizoso, Á., \& López-García, X. (2019). Innovación tecnológica y comunicativa para combatir la desinformación: 135 experiencias para un cambio de rumbo [Technological and communicative innovation to fight misinformation: 135 experiences for a change of direction]. El Profesional de la Información, 28(3), 1-12. https://doi.org/10.3145/epi.2019. may.01

Vosoughi, S., Roy, D., \& Aral, S. (2018). The spread of true and false news online. Science, 359(6380), 1146-1151. https://doi.org/10.1126/science. aap9559

Walter, N., Cohen, J., Holbert, R. L., \& Morag, Y. (2019). Fact-checking: A meta-analysis of what works and for whom. Political Communication, 37(3), 350-375. https://doi.org/10.1080/10584609.2019.1668894

Wardle, C., \& Derakhshan, H. (2017). Information disorder: Toward an interdisciplinary framework for research and policy making. Council of Europe. Retrieved from https://bit.ly/2ECHDj1

Zimmermann, F., \& Kohring, M. (2020). Mistrust, disinforming news, and vote choice: A panel survey on the origins and consequences of believing disinformation in the 2017 German parliamentary election. Political Communication, 37(2), 215-237. https://doi.org/ 10.1080/10584609.2019.1686095 


\section{About the Authors}

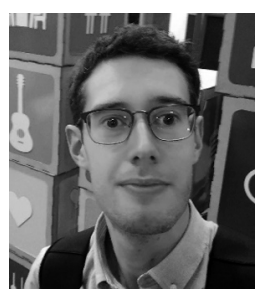

Carlos Rodríguez-Pérez is Lecturer for Journalism at the Department of Journalism and Social Communication at the University of Ibagué (Colombia) where he teaches Digital Journalism. PhD Candidate at the Complutense University of Madrid (Spain). He holds a Combined Degree in Journalism and Audio-visual Communication by Carlos III University of Madrid (Spain) and a MA in Political Communication by IUIOG-Madrid (Spain). His research lines focus on online disinformation and fact-checking journalism. https://orcid.org/0000-0002-4830-5554; Twitter: @CarlosRguezPrez

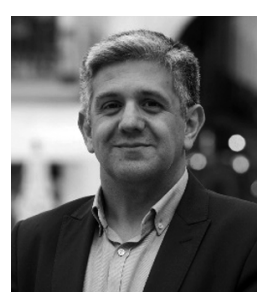

Francisco J. Paniagua-Rojano is Senior Lecturer (Tenured) at the Department of Journalism, at the University of Malaga, where he teaches Corporate Communication and Strategies. His main research lines focus on credibility of media, social media and journalism. He has published more than 40 papers about Journalism, credibility and social media. He has worked as Chief of Communication in the International Andalusian University (2011-2014) and Andalusian Federation of Municipalities and Provinces (2000-2003) Since 2008, he is the secretary of the section about "Corporate Communication, Advertising and Public Relations," in the Spanish Association of Communication Researchers.

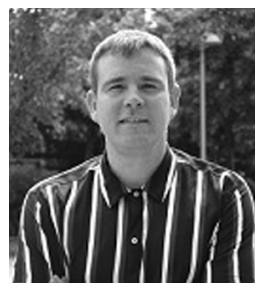

Raúl Magallón-Rosa is Senior Lecturer in Communication Theory at the Department of Communication, Universidad Carlos III de Madrid (Spain). He has an European Doctorate in Communication at Complutense University of Madrid. He is the author of Unfaking News: Cómo Combatir la Desinformación [Unfaking news: How to tackle disinformation] (Pirámide, 2019) and other published articles in peer-reviewed journals on the topic of fake news and fact-checking. 